\title{
Influence of the addition of lupine protein isolate on the protein and technological characteristics of dough and fresh bread with added Brea Gum
}

\author{
Estela Patricia LÓPEZ ${ }^{1 *}$
}

\begin{abstract}
The effect of protein lupine isolate (LI) and addition of brea gum (BG) on a basic bread formulation is described. The major objective of this research was to evaluate the influence of the addition of LI on the quality and quantity of the proteins of fresh bread with BG. Protein quality was determinate by the Chemical Score method corrected for protein digestibility (CSCD\%). The bread dough characteristics were determined by farinograph and alveograph. Fresh bread characterization was performed by measuring the physical parameters and evaluating the crumb structure. The effect of LI and BG on available lysine, the loss of available lysine ratio, and the chemical composition of the breads were also determined. The addition of LI on the bread formulation improved the protein content and the CSCD\% of lysine. The dough with LI was less resistant to prolonged kneading and less manageable. With BG addition, the dough became stickier. The quality of fresh bread was affected by the addition of LI: the fresh bread had lower specific volume and more heterogeneous crumbs than that of the control group. The addition of BG did not influence the quality of the bread made with the mixed flour, but it had a positive effect on the loss of available lysine.
\end{abstract}

Keywords: protein lupine isolate; brea gum; dough characteristics; bread quality.

\section{Introduction}

Bread is one of the basic products in human diet worldwide. This product is one primary sources of energy since it is rich in carbohydrates, but it is poor in quantity and quality of protein (Bowles \& Demiate, 2006). This paper aims at improving the protein content of bread by incorporating lupine protein isolate (LI) (Lupinus mutabillis sweet) in its formulation.

Lupine is a valuable ancient leguminous plant which grows well in different soils and climates. It has been used as food by people of the Andean highlands (Morrow, 1991; Dervas et al., 1999). The main interest in lupine in foods relates to its high content of protein, which is considered as a good source of lysine and is generally poor in sulfur-containing amino acids (Lampart-Szczapa, 1996). The main anti-nutritional substances are various alkaloids of the quinolizidine group (Mohamed \& Rayas-Duarte, 1995). Many lupine varieties have high levels of alkaloids (bitter tasting compounds) that make the seed unpalatable and sometimes toxic (El-Adawy et al., 2001). Lupine alkaloids can be removed from the seed by boiling for 30 minutes, followed by steeping in running water for three days (Rahma \& Narasinga Rao, 2002). In addition, the production of protein isolates can contribute to solving this problem because alkaloids are water-soluble and would be removed during preparation of the isolates; they can then be used as functional ingredients in human food (Souza et al., 1996). Sosulski \& Youngs (1979) mentioned that the protein concentrates and isolates from lupines can be used as an additional source of protein for human nutrition. Lupine protein has a high nutritive value if supplemented with methionine, and it could replace soy concentrate in countries that need to import soybean (Ruiz Junior \& Hove, 1976). Therefore, several authors have incorporated lupine proteins to the formulation of bread (Dervas et al. 1999; Paraskevopoulou et al., 2010; Doxastakis et al., 2002; Bonet et al., 2006).

Hydrocolloids are widely used as additives in the food industry because they can modify the rheology and texture of aqueous suspensions (Dziezak, 1991) due to their high water retention capacity (Lee et al., 2002). In baked goods, hydrocolloids have been used for retarding staling and/or for improving the quality of fresh products (Bárcenas \& Rosell, 2005). In fact, guar, xanthan, arabic, carrageenans, alginates, pectin, and cellulose derivatives have been widely used (Guarda et al., 2004; Sharadanant \& Khan, 2003; Rosell et al., 2001).

Brea gum (BG) is a hydrocolloid obtained as phloematic exudate from Cercidium praecox. The two most common species in Argentina are C. praecox (Brea tree) and C. australe (Brea arbustus). The genus Cercidium belongs to the Leguminosae family. With their extensive root system, Brea trees can be found in semi-arid regions of Argentina. Brea trees grow scattered in the wild, and gums from these untended trees are collected manually by the native people. The exudate gum is obtained from superficial incisions made in the branches and tree trunks. After some weeks, the partially dry gum exudates are manually collected. The exudate is purified by a simple process of solution and subsequent drying and further grinding into a fine powder (López et al., 2013).

The production and composition of the BG is complex and varies somewhat depending on the geographical origin, climatic conditions, and the age of the trees. BG has an amber

Received 09 Jan., 2014

Accepted 27 Jan., 2014 (006271)

${ }^{1}$ Food Laboratory, Faculty of Engineering, Research Institute of Chemical Industry - INIQui, National University of Salta - UNSa, Salta, Argentina, e-mail: epl_81@yahoo.

com.ar

${ }^{*}$ Corresponding author 
colour and a semi-liquid consistency with a faintly sweet flavour. It is highly soluble in water and yields homogeneous acidic solutions $(\mathrm{pH}=4)$. The hydrocolloid contains residues of L-arabinose, D-xylose, D-glucuronic acid, and 4-OmethylD -glucuronic acid in the approximate molar ratios of 1.7:6, 3:1 and 9:0.9, respectively (De Pinto et al., 1993; Cerezo et al., 1969), associated with small amounts of protein (approximately $8 \%)$, which contribute to their emulsifying properties. The major structural features of BG appear to be a $\beta-(1 \rightarrow 4)$-linked $\mathrm{d}$-xylan backbone [possibly containing some $(1 \rightarrow 2)$-linkages] that is 2 -substituted for short branch chains containing residues of d-xylose (and l-arabinose) and d-glucuronic acid, in which both types of residue may be terminal (Cerezo et al., 1969). BG share structural and chemical similarities with other plant gums widely used in the food industry such as the Arabic gum (De Pinto et al., 1993). Therefore, BG could be a suitable candidate for incorporation as stabilizing, emulsifying, and thickening additive in food formulation. Brea gum has been traditionally used as a 'woodland candy' by countryside people since pre-Colombian times without producing harmful consequences. Von Müller et al. (2009) reported a toxicological evaluation of BG in mice. Their results suggest that feeding BG at levels up to $5 \%$ to mice do not exert any toxicological effects, supporting its potential use as a food additive for human consumption.

The addition of BG $(0.5 \% \mathrm{w} / \mathrm{w})$ to flour has proven to improve the texture of stored wheat bread (López et al., 2013), and the emulsifying properties of this hydrocolloid may have contributed to the texture and the structure of the crumb of the fresh bread made with other flours and when the wheat gluten is "diluted".

It should be noted that the use of hydrocolloid in this study aims to test its functionality as a promoting agent of the physical characteristics of fresh bread made with flour mixture. Therefore, the major objective of this research was to evaluate the influence of the addition of LI on the quality and quantity of the proteins of fresh bread with BG.

\section{Materials and methods}

\subsection{Raw materials}

Lupine: healthy and clean Bolivian seeds of Lupinus mutabillis sweet were used, from which protein isolate was obtained.

BG was provided by indigenous communities of Chaco Salteño.

For the bread elaboration, commercial wheat flour (WF) (10\% moisture content, $11.79 \%$ protein and $0.71 \%$ ash), compressed yeast, and other ingredients were purchased from local markets.

\subsection{Mix WF:LI}

The proportion used was WF: LI - 90:10. With this mixture, dough and breads were developed later.
To study the effect of the gum on the characteristics of fresh bread, BG was added to the mixture WF:LI at a rate of $0.5 \% \mathrm{w} / \mathrm{w}$, and dough and breads were also elaborated.

\subsection{Lupine protein isolates (LI)}

Lupine seeds were crushed using a household mill (Braun, Germany) and defatted by soaking in petroleum ether for 20 hours with several changes of the solvent. The defatted flour was air-dried at room temperature $\left(25^{\circ} \mathrm{C}\right)$ and ground again to pass through an 80 -mesh $(0.173 \mathrm{~mm}$ ASTM) sieve. The fine flour was used to prepare the protein isolates. One $\mathrm{kg}$ of lupine flour was suspended in 1:10 distilled water, and the $\mathrm{pH}$ was adjusted to 9.0 using $1 \mathrm{M} \mathrm{NaOH}$. The suspension was stirred for one hour at room temperature and then centrifuged at 3000 $\mathrm{x} g$ for 30 minutes. To obtain higher yields, the extraction and centrifugation were repeated on the residue. The extracts were combined and acidified to $\mathrm{pH} 4.5(\mathrm{HCl} 1 \mathrm{~N})$. The precipitate was recovered by centrifugation at $3000 \mathrm{x} g$ for 30 minutes and then neutralized by $1.0 \mathrm{M} \mathrm{NaOH}$ to $\mathrm{pH} 7$ and washed with distilled water several times. The neutralized precipitate was freeze-dried (Heto CT 110, Heto - Denmark), milled using a household mill (Braun, Germany), and finally sieved through an 80 -mesh (0.173 mm - ASTM).

The following parameters were measured in the LI analysis:

- Nitrogen content: determined using the Kjeldahl method and multiplied by a factor of 6.25 to determine total protein content $(\mathrm{g} \%)$;

- Moisture (g\%): by drying at $105^{\circ} \mathrm{C}$ to constant weight (Association of Offcial Analytical Chemists, 2000);

- Ash and fats (g\%): following the official AOAC methods (Association of Offcial Analytical Chemists, 2000);

- Colour: the CIELAB parameters $\left(L^{*}, a^{*}, b^{*}\right)$ were determined using a ColorTec PCM colorimeter (Accuracy Microsensor Inc., Pittsford, USA), equipped with a light source D65 and an observation angle of $10^{\circ}$.

Each analysis was performed in triplicate.

\subsection{Purified brea gum}

The native BG was purified at the laboratory. First, it was solubilized in water at room temperature, and then it was successively filtered. Once clean, BG was dried in an oven at low temperature and milled to a particle size of 80 mesh $(0.173 \mathrm{~mm}-\mathrm{ASTM})$. Since BG has a high solubility in water $\left(28.3 \%\right.$ at $\left.25^{\circ} \mathrm{C}\right)$, the fine powder was solubilized in the water required for kneading (measured by farinograph analysis) to ensure a good distribution of the hydrocolloid throughout the dough (20). To study the effect of the gum on the characteristics of fresh bread, BG was added $(0.5 \% \mathrm{w} / \mathrm{w})$ to the mixture WF:LI.

\subsection{Pasting properties of the WF:LI blend}

The pasting properties of WF:LI and WF:LI + BG were determined using a Rapid Visco Analyzer (RVA) (RVA 4500-TecMaster, Perten Instruments, USA). The samples were 
prepared by mixing the flour $(3.5 \pm 0.5 \mathrm{~g})$ with $25 \mathrm{ml}$ distilled water. The analysis was performed based on the AACC approved method 76-21.01 (American Association of Cereal Chemists, 2000). The heating and cooling cycles were programmed as follows: The samples were held at $50^{\circ} \mathrm{C}$ for $1 \mathrm{~min}$, heated to $95^{\circ} \mathrm{C}$ in $3.42 \mathrm{~min}$, held at $95^{\circ} \mathrm{C}$ for $2.7 \mathrm{~min}$, cooled to $50^{\circ} \mathrm{C}$ in $3.88 \mathrm{~min}$, and held at $50^{\circ} \mathrm{C}$ for $2.0 \mathrm{~min}$. The following parameters were analyzed in triplicate:

- Pasting temperature $\left({ }^{\circ} \mathrm{C}\right)\left(\mathrm{T}^{\circ} \mathrm{ig}\right)$;

- Peak viscosity (in $\mathrm{cP})(\mathrm{PV})$;

- Viscosity at the end of the heating period or hold (in $\mathrm{cP}$ ) (H);

- Viscosity at $50^{\circ} \mathrm{C}$ (in cP) (C);

- Stability or breakdown (in $\mathrm{CP}$ ), as the difference between $\mathrm{PV}-\mathrm{H}$;

- Setback (in cP) calculated as the difference between the parameters $\mathrm{C}$ - PV.

\subsection{Farinograph procedure}

The dough mixing properties of the WF:LI and WF:LI+GB blends were evaluated using the Brabender farinograph (Brabender, Duisburg, Germany), according to the procedure of AACC (American Association of Cereal Chemists, 1983). The parameters evaluated were:

- Water absorption (WA) or percentage of water required to achieve a dough consistency of $500 \mathrm{BU}$ (Brabender Units);

- Development time (DT, time required to reach maximum consistency, expressed in minutes);

- Stability ( $\mathrm{S}$, time during which the dough is maintained at 500UB, expressed in minutes);

- Softening or relaxation of the dough (So, drop dough consistency after 12 minutes from the onset of peak in $\mathrm{UB}$ ); and

- Farinograph quality number FQN expresses a singular number that allows the comparison of the baking quality of flour: weak flours shown a low FQN) (Wang et al., 2002; Gómez Pallares et al., 2007).

The test was performed in triplicate for each sample.

\subsection{Alveograph procedure}

This procedure was performed using an alveograph (Model Alveographe NG, Chopin, France) according to the AACC method (American Association of Cereal Chemists, 2000) and determining the following parameters

- $\mathrm{P}$ (dough resistance to deformation, in $\mathrm{mm}$ );

- L (extensibility of the dough, in $\mathrm{mm}$ );

- P/L (ratio between tenacity and dough extensibility);

- W (strain energy or baking strength) (Gómez Pallares et al., 2007; Miralbés, 2004; Rosell et al., 2001).
The test was performed in triplicate for each sample.

\subsection{Baking test}

The dough was prepared using the following proportions of ingredients based on 100g of WF:LI and WF:LI+BG mixtures: dried yeast $1 \%$, salt $1.6 \%$, and water according to the WA.

The ingredients were mixed (for 10 minutes) and kneaded using a commercial bread maker machine (ATMA easy cook). The dough was fermented at $27^{\circ} \mathrm{C}$ for $95 \mathrm{~min}$ and kneaded for $25 \mathrm{~min}$. Baking was performed at $150^{\circ} \mathrm{C}$ for $60 \mathrm{~min}$. Finally, the bread was cooled to room temperature for 120 minutes. The loaves were placed unpacked into a special camera and stored at $25^{\circ} \mathrm{C} \pm 2{ }^{\circ} \mathrm{C}$ with a $75-80 \%$ relative humidity for 2 hours. Three pieces of each type of bread (WF:LI and WF:LI+BG) were taken and stored for analysis.

\subsection{Evaluation of fresh bread quality characteristics}

Each loaf was characterized by:

- Volume (rapeseed displacement) (V);

- Specific volume index: specific volume of the control loaves were taken as 100 , and the specific volume of the samples with BG was referred to the value assigned to the control (SVI);

- Width/height ratio of the central slice $(\mathrm{W} / \mathrm{H})$;

- Analysis of the crumb structure: performed by scanning and digitizing the crumb image. Images were taken from the centre of the each bread slice and were captured using an Epson scanner (Epson Stylus CX5900). Crumb cells were analyzed by ImageJ software version 1.44 (Wayne Resband National Institute of Health, USA). This software allows the selection of the central image of the crumb and determines the area expressed in $\mathrm{mm}^{2}$ (I). It then converts it to an 8-bit image to obtain a black and white threshold, allowing a clear distinction between black cells. This allows the calculation of the average cell size $(\mathrm{mm})$, the number of cells present in the selected area (II), and the total area occupied by cells (\% area fraction). To calculate the number of cells per $\mathrm{cm}^{2}$, first, the value (I) is converted to $\mathrm{cm}^{2}$, then the ratio of the parameters (I) and (II) is calculated.

The total cell area (\%) (TCA), the average size of the cells $(\mathrm{mm})\left(\right.$ ASC), and the number of cells per unit area $\left(\mathrm{C} / \mathrm{cm}^{2}\right)$ were calculated.

Three replicates for each sample were carried out.

\subsection{Protein quality and chemical composition of the loaves.}

- Protein quality was analyzed based on the chemical score corrected for digestibility (CSCD \%) The pattern of amino acid recommended by the FBN/IOM (Food and Nutrition Board \& Institute of Medicine, 2002) for preschoolers was used; 
Table 1. Chemical composition and colour profile of WF and LI.

\begin{tabular}{|c|c|c|c|c|c|c|c|c|}
\hline & \multicolumn{3}{|c|}{ Colour } & \multirow{2}{*}{$\begin{array}{c}\text { Moisture } \\
\text { g\% }\end{array}$} & \multirow{2}{*}{$\begin{array}{l}\text { Ash } \\
\text { g\% }\end{array}$} & \multirow{2}{*}{$\begin{array}{c}\text { Proteins } \\
\mathrm{g} \%\end{array}$} & \multirow{2}{*}{$\begin{array}{c}\text { Carbohydrates } \\
\mathrm{g} \% \\
\end{array}$} & \multirow{2}{*}{$\begin{array}{l}\text { Fat } \\
\mathrm{g} \%\end{array}$} \\
\hline & $\mathrm{L}^{*}$ & $a^{*}$ & $b^{*}$ & & & & & \\
\hline WF & $94.2 \pm 1.3 \mathrm{a}$ & $4.5 \pm 0.4 \mathrm{a}$ & $6.8 \pm 0.7 \mathrm{a}$ & $10.0 \pm 0.8 \mathrm{a}$ & $0.7 \pm 0.2 \mathrm{a}$ & $11.8 \pm 0.2 \mathrm{a}$ & $70.2 \pm 1.8 \mathrm{~b}$ & $1.5 \pm 0.6 \mathrm{a}$ \\
\hline LI & $85.0 \pm 3.5 b$ & $7.0 \pm 0.4 \mathrm{~b}$ & $25.1 \pm 1.3 b$ & $3.2 \pm 0.7 \mathrm{~b}$ & $0.8 \pm 0.2 b$ & $92.3 \pm 0.4 \mathrm{~b}$ & $3.3 \pm 0.4 \mathrm{a}$ & $0.09 \pm 0.0 \mathrm{~b}$ \\
\hline
\end{tabular}

Means \pm standard deviations. Values in the column followed by the same letter are not significantly different $(p<0.05)$.

- Available lysine (AL) (six replicates) in the flours (WF, WF:LI, and WF:LI + BG) and fresh breads was determined following the Carpenter method, modified by Booth (1971). The loss rate of AL (dry basis) was calculated by the following formula:

$$
\text { Loss rate }(\%)=(\text { AL bread } * 100) / \text { AL flour }
$$

- The chemical composition was determined (in triplicate) in the fresh breads in terms of moisture, ash, and fats ( $\mathrm{g} \%$ ), following the AOAC methods (Association of Offcial Analytical Chemists, 2000), protein (g\%) by the Kjeldhal method using a 6.25 factor for conversion, and carbohydrates $(\mathrm{g} \%)$ by difference.

\section{Statistical analysis}

The data obtained was subjected to analysis of variance (ANOVA) and Tukey's test using the software program of Statistical Package for the Social Sciences (SPSS, 17.0) to assess significant differences among the samples. Differences were considered significant when $p<0.05$.

\section{Results and Discussion}

\subsection{Lupine protein isolates (LI)}

Table 1 presents the chemical composition and the colour profile of the WF and LI obtained.

LI had the appearance of a fine powder ( 80 mesh -0.173 mm ASTM), and a creamy yellow colour. It was significantly more opaque than WF. LI protein content was $92 \%$, and it showed lower values of fats, carbohydrates, and moisture than those of WF. The chemical composition of LI was very similar to that reported by El-Adaway et al. (2001), who analyzed a sample of LI obtained by alkaline water extraction/isoelectric precipitation (protein: $91.2 \mathrm{~g} \%$; Ash: $1.26 \mathrm{~g} \%$; moisture: $2.93 \mathrm{~g} \%$; fats: $0.15 \mathrm{~g} \%)$.

\subsection{Pasting properties of the WF:LI blend}

Table 2 shows the viscosity profile of control flour and WF: LI blend, with and without the addition of BG.

Table 2 Pasting temperature or gelatinization onset temperature $\left(\mathrm{Tig}^{\circ}\right)$ is a measure of the minimum temperature required to cook a sample of a given food (Sandhu, 2007). It may affect the stability of other components of the formula and is an indicator of the energy costs (Newport Scientific, 1998). In the WF:LI mixture, with and without the addition of BG, the pasting temperature was not significantly different from that of the WF.
Table 2. Viscosity profile of the control flour and the WF: LI mixture, with and without addition of BG.

\begin{tabular}{cccc}
\hline & \multirow{2}{*}{ Control } & \multicolumn{2}{c}{ WF:LI-90:10 } \\
\cline { 3 - 4 } & & Without BG & With BG \\
\hline PV (cP) & $2658 \pm 62 \mathrm{c}$ & $2374 \pm 11 \mathrm{~b}$ & $2172 \pm 18 \mathrm{a}$ \\
$\mathrm{H}(\mathrm{cP})$ & $1680 \pm 28 \mathrm{a}$ & $1795 \pm 3 \mathrm{ab}$ & $1822 \pm 38 \mathrm{~b}$ \\
$\mathrm{C}(\mathrm{cP})$ & $3062 \pm 83 \mathrm{~b}$ & $3062 \pm 58 \mathrm{~b}$ & $3119 \pm 65 \mathrm{~b}$ \\
Breakdown $(\mathrm{cP})$ & $978 \pm 32 \mathrm{c}$ & $579 \pm 28 \mathrm{~b}$ & $350 \pm 30 \mathrm{a}$ \\
Setback $(\mathrm{cP})$ & $404 \pm 25 \mathrm{a}$ & $688 \pm 42 \mathrm{~b}$ & $947 \pm 10 \mathrm{c}$ \\
Tig $\left({ }^{\circ} \mathrm{C}\right)$ & $66.9 \pm 0.3 \mathrm{a}$ & $67.6 \pm 0.7 \mathrm{a}$ & $67.8 \pm 1.2 \mathrm{a}$ \\
\hline
\end{tabular}

Means \pm standard deviations. Values in the rows followed by the same letter are not significantly different $(\mathrm{p}<0.05) . \mathrm{T}^{\circ}$ ig: Pasting temperature; PV: Peak viscosity; H: Viscosity at the end of the heating period or hold; C: Viscosity at $50^{\circ} \mathrm{C}$.

This finding is consistent with that the reported by Funami et al. (2008), who added $0.5 \%$ of Arabic gum to a suspension of wheat starch.

The WF:LI mixture showed significant differences $(\mathrm{p}<0.05)$ when compared to control, resulting in lower peak viscosity. This finding was consistent with that reported by King et al. (1985), who observed a decrease in the maximum viscosity with the addition of soy protein isolate to a suspension of mung bean starch. This decrease can be related to the lower swelling capacity of wheat starch granules (diluted by the addition of LI) since the starch would compete with the LI proteins for the available water. The peak decreased even more with BG addition, which can be due to lower availability of water for starch.

Breakdown is considered a measure of the degree of disintegration of the granules of the paste (Newport Scientific, 1998; Dengate, 1984) and is an indicator of the stability of the starch gel during baking (Zaidul et al., 2006). Higher damage values are associated with greater peak viscosities, which in turn are related to the degree of swelling of the starch granules during heating (Ragaee \& Abdel-Aal, 2006). Since more highly swollen starch granules are present in the system, the viscosity at the peak is higher. Therefore, the WF: LI mixture had significant differences $(p>0.05)$ in the final viscosity from that of the control flour since the smaller rupture of granules in the mixture led to a decrease in the final viscosity and thus, the gel stability was higher. The setback values were significantly higher for WF: LI, particularly for WF:LI +BG, in than that of the WF. This effect observed on the mixture with added BG, could be explained by a process of phase separation that is related to an incompatibility phenomenon between starch and gum since both polymers would not be linked (Alloncle \& Doublier, 1991). Both polysaccharides exhibited mutual exclusion based on thermodynamic incompatibility (Funami et al., 2008; Alloncle \& Doublier, 1991; Annable et al., 1994); resulting in an increased 
synergy of the composite system. This can explain the decrease in the value of PV and the lower amount of lixiviated amylose.

\subsection{Rheological behavior of the dough}

The results of the farinograph and alveograph analysis of the dough of WF, WF: LI, and WF: LI + BG blends are described in Table 3.

\section{Farinograph analysis}

The WA (Table 3) was significantly higher $(\mathrm{p}<0.05)$ in the flour blend. In the WF:LI dough, this increase can be explained by the addition of a significant amount of protein to the WF, which is consistent with the finding reported by Paraskevopoulou et al. (2010), who combined wheat flour with lupine protein isolate at 10 and $5 \% \mathrm{w} / \mathrm{w}$.

Other authors have also reported an increase in the WA with the addition of vegetable protein to wheat flour, and they have attributed this phenomenon to the ability of proteins to compete for water with other constituents in the dough system.

According to these authors, the ability of these proteins to absorb high amounts of water in the dough resulted in an increase in the farinograph water absorption values (Doxastakis et al., 2002; Dervas et al., 1999; El-Soukkary, 2001; El-Adawy, 1997).

The amount of water added is considered very important for the distribution of the different components of the dough, hydration and development of the gluten network. WA also increased with the addition of BG, given the ability of the gum to retain water due to the presence of hydroxyl groups in the hydrocolloid structure. These groups allow more interaction between water molecules through hydrogen bond formation.

This finding is in agreement with that reported by Rosell et al. (2001), in a study on the effect of the addition of alginate and HPMC on the formulation of bread, and with that reported by Friend et al. (1993) who added xanthan gum and HPMC to the tortilla dough.

The development time (DT) (Table 3) is considered as the time required for the consistency of the dough to reach 500 BU. By adding $\mathrm{LI}$ to the WF, there was a significant $(\mathrm{p}<0.05)$ decrease in the time required to achieve a dough of $500 \mathrm{BU}$, which can be explained by the smaller amount of wheat storage proteins present in the mixtures, causing the early developed of gluten by the increased presence of water in the system. In the particular case of the WF:LI + BG mixture, the DT was lower than that observed for the mixture without BG, which could be explained by the presence of the hydrocolloid, which increases the viscosity of the system by requiring an even greater amount of water for dough forming. Furthermore, the greater presence of water leads to starch hydration, causing an increase in paste viscosity.

Stability (S) of the dough made from the mixtures of flour, with or without BG (Table 3), was significantly lower than that of the control $(\mathrm{p}<0.05)$. This behavior is justified by the fact that the quantity and quality of gluten formed were lower because WF proteins would be diluted and possibly there would be a mechanical effect of disruption of the gluten network caused by the particles of LI (10). Güemes-Vera et al. (2004), who carried out a structural analysis of dough made from blends of wheat flour with lupine flour as well as concentrate and lupine protein isolates, reported that the vegetable protein present in the mixture resulted in disruption of the structure of the dough.

The degree of softening or drop dough consistency (So, Table 3) was higher $(\mathrm{p}<0.05)$ in the dough made with flour mixture and was even higher in the dough with $B G$ added. So is an indicator of the kneading resistance; thus, it was concluded that the flour mixture dough was less tolerant to mechanical action, which could be explained by the interruption of the dough structure caused by the presence of the LI proteins and the weakening of the gluten formed, as reported by GüemesVera et al.(2004). The addition of the hydrocolloid led to a larger decrease in consistency, which can be related to the decrease in the DT and S. Similar results were reported by Wang et al. (2002) who evaluated the addition of different fibers to bread dough.

These results explain the decrease in FQN (Table 3) since a reduction in this indicator shows a weakening of the dough (Miralbés, 2004).

\section{Alveograph analysis}

Table 3 also presents the results of the farinograph and alveograph analysis performed in the flour mixture dough.

The tenacity of the dough or dough resistance to deformation $(\mathrm{P})$ is a measure of the ability of the dough to hold the gas produced during fermentation. When LI was added, the parameter P did not change; according to Paraskevopoulou et al. (2010), this behavior is due to the strengthening of the gluten network caused by the occlusion of the LI protein within this network.

On the other hand, the extensibility (L) of the dough was strongly increased $(p<0.05)$ with the presence of LI. This behavior resulted in softer dough, which is justified by the presence of more water in the system and the lower strength of the gluten formed. Therefore, the $\mathrm{P} / \mathrm{L}$ ratio (Table 3 ) or balance (which is a measure of the elastic resistance and balance dough

Table 3. Farinograph and alveograph parameters of the dough made with flour mixture and addition of BG.

\begin{tabular}{cccccccccc}
\hline & WA (\%) & So (BU) & DT (B) & S (BU) & FQN & P $(\mathrm{mm})$ & $\mathrm{L}(\mathrm{mm})$ & P/L & W \\
\hline WF & $53.7 \pm 0.1 \mathrm{a}$ & $29.0 \pm 0.3 \mathrm{a}$ & $9.0 \pm 0.5 \mathrm{c}$ & $18.0 \pm 0.6 \mathrm{c}$ & $201 \pm 1 \mathrm{c}$ & $130 \pm 7 \mathrm{~b}$ & $29 \pm 1 \mathrm{a}$ & $4.6 \pm 0.4 \mathrm{~b}$ & $174 \pm 1 \mathrm{a}$ \\
WF:LI & $56.8 \pm 0.1 \mathrm{~b}$ & $32.8 \pm 0.9 \mathrm{~b}$ & $6.5 \pm 0.4 \mathrm{~b}$ & $12.5 \pm 0.5 \mathrm{~b}$ & $188 \pm 4 \mathrm{~b}$ & $133 \pm 10 \mathrm{~b}$ & $46 \pm 2 \mathrm{~b}$ & $2.9 \pm 0.5 \mathrm{a}$ & $251 \pm 9 \mathrm{~b}$ \\
WF:LI+BG & $58.4 \pm 0.2 \mathrm{c}$ & $35.5 \pm 0.7 \mathrm{c}$ & $4.1 \pm 0.4 \mathrm{a}$ & $9.5 \pm 0.4 \mathrm{a}$ & $132 \pm 4 \mathrm{a}$ & $130 \pm 7 \mathrm{~b}$ & $49 \pm 1 \mathrm{~b}$ & $2.7 \pm 0.5 \mathrm{a}$ & $230 \pm 6 \mathrm{~b}$ \\
\hline
\end{tabular}

Means \pm standard deviations. Values in the columns followed by the same letter are not significantly different $(\mathrm{p}<0.05)$. WA: water absorption; So: softening or relaxation; DT:

development time; S: stability; FQN: farinograph Quality Number; P: resistance; L: extensibility; P/L: Resistance/extensibility ratio; W: baking strength. 
extensibility) (Rosell et al., 2001) decreased significantly in the flour mixture dough, and it was more extensible than tenacious resulting in softer and sticky dough. A similar effect was reported by Dervas et al. (1999), who added whole lupine flour, concentrate of defatted lupine flour, and lupine concentrate flour to the wheat flour dough.

The addition of BG to $0.5 \%$, appears to have no influence on the tenacity and extensibility of the flour mixture dough (compared with that of the WF:LI blend), perhaps because the amount added was very low and the effect on the alveographic parameters would be more likely related to the addition of LI.

The baking strength (W) or energy needed to deform the dough until it breaks (Osorio \& Aristizabal Henao Galvis, 2009) (Table 3) was significantly increased with the addition of LI, and this behavior can be explained by the fact that the dough was more extensible, and thus it can resist the deformation forces. Therefore, the force needed to break the structure is greater.

\subsection{Evaluation of fresh bread quality characteristics}

Table 4 summarizes the data obtained in the evaluation of the quality of the fresh breads made with the flour blend and compares the parameters with those of the control.

The breads made with WF:LI showed a significant reduction ( $p<0.05)$ in the SV compared with that of the control, which resulted in a marked decrease in the IVE in the WF:LI bread. These results agree with those obtained in the farinograph and alveograph analysis and also with those reported by Paraskevopoulou et al. (2010), Doxastakis et al. (2002) and Dervas et al. (1999).

The width/height ratio $(\mathrm{W} / \mathrm{H})$, which is a measure of the slice shape, showed that breads made with the flour mixture were lower in volume since the slices were wider than higher.

Significant differences in the size and distribution of the cells were observed (Table 4 ). Breads crumbs made with the flour blends had a lower average size of cells and hence greater amount of cells per unit area (Table 4).

This resulted in a lower area fraction, which is directly related to the volume of the bread. Thus, the fraction of the area showed a high positive correlation with the average cell size $(\mathrm{r}=0.97)$ and $\mathrm{SV}(\mathrm{r}=0.95)$.

The WF: LI + BG bread had very similar values to those found for the WF: LI bread. The presence of BG did not improve the quality of the fresh bread, probably because it is not a gum with structural properties such as those of HPMC and xanthan gum. At the same time, it is important to note that this gum did not deteriorate the bread quality as do alginates (American Association of Cereal Chemists, 1983).

\subsection{Protein quality and chemical composition of the loaves.}

\section{Chemical Score}

Table 5 summarizes the results of the calculation of the chemical score (CS \%) corrected for digestibility (CSCD \%) for
Table 4. Quality parameters of fresh control bread and fresh bread made from a blend of WF:LI.

\begin{tabular}{cccc}
\hline Parameter & WF bread & WF:LI bread & WF:LI+BG \\
\hline SV & $2.26 \pm 0.05 \mathrm{a}$ & $2.13 \pm 0.12 \mathrm{~b}$ & $2.10 \pm 0.16 \mathrm{~b}$ \\
SVI & $100 \mathrm{a}$ & $94 \mathrm{~b}$ & $93 \mathrm{~b}$ \\
$\mathrm{~W} / \mathrm{H}$ & $1.19 \pm 0.06 \mathrm{a}$ & $1.73 \pm 0.20 \mathrm{~b}$ & $1.71 \pm 0.10 \mathrm{~b}$ \\
Average cell size $(\mathrm{mm})$ & $3.84 \pm 0.03 \mathrm{a}$ & $2.82 \pm 0.02 \mathrm{~b}$ & $2.75 \pm 0.05 \mathrm{~b}$ \\
Area fraction $(\%)$ & $30.55 \pm 1.99 \mathrm{a}$ & $28.90 \pm 1.13 \mathrm{~b}$ & $27.93 \pm 0.10 \mathrm{~b}$ \\
$\mathrm{~N}^{\circ}$ cells $/ \mathrm{cm}^{2}$ & $7.97 \pm 0.42 \mathrm{a}$ & $9.03 \pm 0.11 \mathrm{~b}$ & $8.93 \pm 0.20 \mathrm{~b}$ \\
\hline
\end{tabular}

Means \pm standard deviations. Values in the rows followed by the same letter are not significantly different $(p<0.05)$. SV: specific volume; SVI: Specific Volume Index; W/H: width / height ratio.

Table 5. Chemical Score corrected by digestibility

\begin{tabular}{cccccc}
\hline \multirow{2}{*}{ Flour/blend } & \multicolumn{2}{c}{ Lysine } & & \multicolumn{2}{c}{ Methionine-Cystine } \\
\cline { 2 - 3 } \cline { 5 - 6 } & CS $\%$ & CSCD $\%$ & & CS \% & CSCD $\%$ \\
\hline WF & 45 & 43 & & 175 & 168 \\
LI & 104 & $93^{\star}$ & & 86 & $77^{\star}$ \\
WF:LI 90:10 & 92 & 82 & & 176 & 157
\end{tabular}

${ }^{*} \mathrm{CSCD} \%$ according to data published by El-Adawy (2001).

the limiting amino acids of the control flour, the LI, and their mixture (WF:LI - 90:10).

The WF:LI mixture showed the greatest CS\% that had the highest percentage of lysine corrected for digestibility, which was expected since the anti-nutrients were removed and the protein was concentrated (El-Adawy et al., 2001). Using the mixture WF:LI - 90:10, the protein quality of WF was improved by $90.7 \%$ due to high protein contribution, and therefore the concentration of lysine (the limiting amino acid of the WF) was higher.

\section{Available lysine $(A L)$}

The bread with the addition of LI showed greater AL values (Figure 1$)$ with significant difference $(\mathrm{p}<0.05)$. This result was expected since LI contributed to the lysine increase.

The addition of BG to the formulations did not affect at all the availability of lysine in the breads, but it caused a significantly decrease in the loss rate of AL (Figure 1) in the breads with BG, when compared with those without the gum. This could be due to the higher moisture content of the crumbs with the addition of the hydrocolloid. The influence of BG on the loss rate of $\mathrm{AL}$ was more important in the control breads because in the other breads, the effect of the gum was softened by the presence of greater amount of protein compounds with high capacity of moisture retention.

\section{Chemical composition of breads}

Table 6 shows the chemical composition of the different breads made for this research.

The WF:LI breads had the highest protein content. The addition of BG changed only the moisture content and did not 
Table 6. Chemical composition of control and WF:LI breads.

\begin{tabular}{cccccc}
\hline Breads & Moisture g\% & Ash g\% & Proteins g\% & Fat g\% & Carbohydrates g\% \\
\hline WF & $44.60 \pm 0.17 \mathrm{a}$ & $0.51 \pm 0.04 \mathrm{a}$ & $8.46 \pm 1.08 \mathrm{a}$ & $0.86 \pm 0.02 \mathrm{a}$ & $45.30 \pm 2.63 \mathrm{~b}$ \\
WF:LI & $46.58 \pm 0.37 \mathrm{~b}$ & $0.54 \pm 0.02 \mathrm{ab}$ & $13.97 \pm 1.14 \mathrm{~b}$ & $0.88 \pm 0.01 \mathrm{a}$ & $37.87 \pm 1.93 \mathrm{a}$ \\
WF:LI +BG & $47.55 \pm 0.15 \mathrm{c}$ & $0.55 \pm 0.08 \mathrm{~b}$ & $14.05 \pm 1.06 \mathrm{~b}$ & $0.87 \pm 0.08 \mathrm{a}$ & $36.38 \pm 2.06 \mathrm{a}$ \\
\hline
\end{tabular}

Means \pm standard deviations. Values in the columns followed by the same letter are not significantly different $(\mathrm{p}<0.05)$.

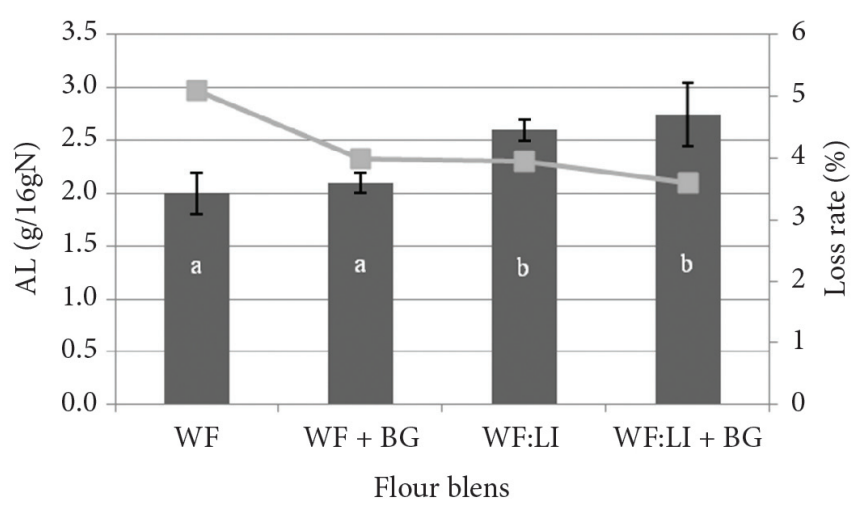

Figure 1. $\mathrm{AL}(\mathrm{g} / 16 \mathrm{gN})$ and loss rate of $\mathrm{AL}(\%)$ in the control and WF:LI breads, with and without addition of BG. Means and S.D. $(n=6)$. Different letters on the bars denote significant differences $(\mathrm{p}<0.05)$.

affect the carbohydrate or protein content since the degree of addition was the minimum necessary for the hydrocolloid to act as a food additive.

The addition of LI to the formulation of bread increased the protein content by $65 \%$ compared with that of the control bread.

This increase was significant because it contributed to increase protein intake according to the daily reference value (\% DRV) for protein (Food and Drug Administration, 2009). A serving of $50 \mathrm{~g}$ of bread made with the addition of $10 \%$ of LI provides $13.97 \%$ of the DRV for protein, representing a significant percentage considering that bread, in general, is not a source of this nutrient.

The caloric value of the WF:LI bread was $215 \mathrm{kcal} \%$, while that of the WF: LI + BG bread was $210 \mathrm{kcal} \%$. There were no significant differences in the calories between the breads with LI and the control bread (223 kcal\%). It should be noted that the breads made with the flour mixture had the same caloric value of that of the control bread since the control bread had a significantly higher content of carbohydrates and the breads with LI had a significantly higher protein content.

\section{Conclusion}

The addition of LI to bread formulations substantially increases the protein content of the product; a serving of $50 \mathrm{~g}$ of bread provide $13 \%$ of the DRV. As for to the protein quality, the WF:LI blend improves the CSCD\% for lysine up to $90.7 \%$ in comparison with that of the control.

The dough with LI was less stable and less resistant to prolonged kneading, less tenacious and more extensible than the control dough, and therefore, less manageable. The addition of
BG affects mainly the WA, stability, and resistance to prolonged mixing, which was due to incorporating the hydrocolloid; the dough became stickier, which was expected due to the higher water content thereof.

The characteristics of the fresh bread were affected by the addition of LI since the WF:LI bread had lower specific volume and heterogeneous crumbs. This result is results from the dilution of the gluten of wheat flour and the higher water content. The addition of BG did not influence the quality of the mixed flour bread, but it showed a positive effect on the loss rate of available lysine because the increased water content of the crumb containing BG appears to have a protective effect on the loss of available lysine.

\section{Acknowledgments}

The authors wish to thank Professor Mark Shaw for his invaluable help with the correction of language.

\section{References}

Alloncle, M., \& Doublier, J. L. (1991). Viscoelastic properties of maize starch/hydrocolloid pastes and gels. Food Hydrocolloids, 5(5), 455467. http://dx.doi.org/10.1016/S0268-005X(09)80104-5

American Association of Cereal Chemists - AACC. (1983). Approved methods of the AACC (Method 54-21, appr. Apr 1961, rev. Oct 1982, 8th ed.). St Paul: AACC.

American Association of Cereal Chemists - AACC. (2000). Approved Methods of the American Association of Cereal Chemists (Method 76-21.01, 10th ed.). St Paul: AACC.

Annable, P., Fitton, M. G., Harris, B., Phillips, G. O., \& Williams, P. A. (1994). Phase behavior and rheology of mixed polymers system containing starch. Food Hydrocolloids, 8(3-4), 351-359. http://dx.doi. org/10.1016/S0268-005X(09)80347-0

Association of Offcial Analytical Chemists - AOAC. (2000). Offcial methods of Analysis (17th ed.). Washington: AOAC.

Bárcenas, M. E., \& Rosell, C. M. (2005). Different approach for improving the quality and extending the shelf-life of the partially baked bread: low temperatures and hydrocolloid addition. Food Chemistry, 100, 1594-1601. http://dx.doi.org/10.1016/j. foodchem.2005.12.043

Bonet, A., Blaszczak, W., \& Rosell, C. M. (2006). Formation of Homopolymers and Heteropolymers Between Wheat Flour and Several Protein Sources by Transglutaminase-Catalyzed CrossLinking. Cereal chemistry, 83(6):655-622.

Booth, V. H. (1971). Problems in the Determination of FDNB-Available Lysine. Journal of Food Science and Agriculture, 22(12), 658-666. http://dx.doi.org/10.1002/jsfa.2740221214

Bowles, S., \& Demiate, I. M. (2006). Physicochemical characterization of the soymilk by product - okara. Ciência e Tecnologia de 
Alimentos, 26(3), 652-659. http://dx.doi.org/10.1590/S010120612006000300026

Cerezo, AS., Stacey, M., \& Webber, J. M. (1969). Some structural studies of Brea Gum (an exudate from Cercidium australe Jonhst). Carbohydrate research, 9(4):505-517. http://dx.doi.org/10.1016/ S0008-6215(00)80035-X

De Pinto, G., Rodriguez, O., Martinez, M., \& Rivas, C. (1993). Composition of Cercidium praecox gum exudates. Biochemical Systematics and Ecology, 21(2), 297-300. http://dx.doi. org/10.1016/0305-1978(93)90048-V

Dengate, H. N. (1984). Swelling, pasting, and gelling of wheat starch. In Y. Pomeranz (Ed.), Advances in Cereal Science and Technology (cap. 2, pp. 49-82). AACC.

Dervas, G., Doxastakis, G., Hadjisavva-Zinoviadi, S., \& Triantaafillakos, N. (1999). Lupine flour addition to wheat flour dough and effect on rheological properties. Food Chemistry, 66(1), 67-73. http://dx.doi. org/10.1016/S0308-8146(98)00234-9

Doxastakis, G., Zafiriadis, I., Irakli, M., \& Tananaki, C. (2002). Lupine, soya and triticale addition to wheat flour doughs and their effect on rheological properties. Food Chemistry, 77(2), 219-227. http:// dx.doi.org/10.1016/S0308-8146(01)00362-4

Dziezak, J. D. (1991). A focus on gums. Food Technology, 45(3), 115-132.

El-Adawy, T. A. (1997). Effect of sesame seed protein supplementation on the nutritional, physical, chemical and sensory properties of wheat flour bread. Food Chemistry, 59(1), 7-14. http://dx.doi. org/10.1016/0308-8146(95)00197-2

El-Adawy, T. A., Rahma, E. H., El-Bedawy, A. A., \& Gafar, A. M. (2001). Nutritional potential and functional properties of sweet and bitter lupine seed protein isolates. Food Chemistry, 74, 455-462. http:// dx.doi.org/10.1016/S0308-8146(01)00163-7

El-Soukkary, E. A. H. (2001). Evaluation of pumpkin seed products for bread fortification. Plant Foods for Human Nutrition, 56(4), 365384. PMid:11678442. http://dx.doi.org/10.1023/A:1011802014770

Food and Drug Administration - FDA. (2009). Guidance for Industry: Guide to food labeling. Retrieved from http://www.fda.gov/food/ guidanceregulation/guidancedocumentsregulatoryinformation/ labelingnutrition/ucm247936.htm.

Food and Nutrition Board, \& Institute of Medicine. (2002). Dietary Reference Intakes for Energy; 2002. Washington: The National Academies Press. Retrieved from http://books.nap.edu/ books/0309085373/html/96.html\#pagetop.

Friend, C. P., Waniska, R. D., \& Rooney, L. W. (1993). Effects of hydrocolloids on processing and qualities of Wheat Tortillas. Cereal Chemistry, 70(3), 252-256.

Funami, T., Nakauma, M., Noda, S., Ishihara, S., Asai, I., Inouchi, N., \& Nishinari, K. (2008). Effect of some anionic polysaccharides on the gelatinización and retrogradation behaviors of wheat starch: Soybean-soluble polysaccharide and gum Arabic. Food hydrocolloids, 22, 1528-1580. http://dx.doi.org/10.1016/j.foodhyd.2007.10.008

Gómez Pallares, M., León, A. E., \& Rosell, C. (2007). Trigo. In A. E. León \& M. C. Rosell (Eds.), De tales harinas, tales pane (cap. 1, pp. 19 -62). Córdoba: Ed. De la Universidad Nacional de Córdoba.

Guarda, A., Rosell, C. M., Benedito, C., \& Galotto, M. J. (2004). Different hydrocolloids as bread improvers and antistaling agents. Food Hydrocolloids, 18(2), 241-247. http://dx.doi.org/10.1016/ S0268-005X(03)00080-8

Güemes-Vera, N., Arciniega-Ruiz Esperza, O., \& Dávila-Ortiz, G. (2004). Structural analysis of the Lupinus Mutabilis seed, its flour, concentrate, and isolate as well as their behavior when mixed with wheat flour. LWT - Food Science and Technology, 37(3), 283-290. http://dx.doi.org/10.1016/j.lwt.2003.07.001

King, J., Aguerre, C., \& De Pablo, S. (1985). Functional properties of lupine protein isolates (Lupinus albus cv Multolupa). Journal of Food Science, 50(1), 82-87. http://dx.doi.org/10.1111/j.1365-2621.1985. tb13282.x

Lampart-Szczapa, E. (1996). Preparation of protein from lupine seeds. Nahrung, 40(2), 71-74. http://dx.doi.org/10.1002/food.19960400205

Lee, M. H., Baek, M. H., Cha, D. S., Park, H. J., \& Lim, S. T. (2002). Freeze-thaw stabilization of sweet potato starch gel by polysaccharide gums. Food Hydrocolloids, 16(4), 345-352. http:// dx.doi.org/10.1016/S0268-005X(01)00107-2

López., E. P., Pérez, G. T., Jiménez, P. L., \& Cuevas, C. M. (2013). Effect of Brea Gum on the characteristics of wheat bread at different storage times. Food Science and Technology, 33(4). In press.

Miralbés, C. (2004). Quality control in the milling industry using near infrared transmittance spectroscopy. Food Chemistry, 88(4), 621628. http://dx.doi.org/10.1016/j.foodchem.2004.05.004

Mohamed, A. A., \& Rayas-Duarte, P. R. (1995). Composition of Lupinus albus. Cereal Chemistry, 72, 634-647.

Morrow, B. (1991). The rebirth of legumes. Food Technology, 45(9), 96-121.

Newport Scientific. (1998). Applications manual for the Rapid Visco Analyzer using thermocline for windows (pp. 2-26). Newport Scientific Pty Ltd.

Osorio, S., \& Aristizabal Henao Galvis, J. (2009). Influencia de la variedad de yuca y nivel de sustitución de harinas compuestas sobre el comportamiento reológico en panificación. Ingeniería e Investigación, 29(1), 39-46.

Paraskevopoulou, A., Provayiduo, E., Tsotiu, V., \& Kiosseoglou, V. (2010). Dough rehology and baking performance of wheat flourlupine protein isolate blends. Food Research International, 43(4), 1009-1016. http://dx.doi.org/10.1016/j.foodres.2010.01.010

Ragaee, S., \& Abdel-Aal, E. M. (2006). Pasting properties of starch and protein in selected cereals and quality of their food products. Food Chemistry, 95(1), 9-18. http://dx.doi.org/10.1016/j. foodchem.2004.12.012

Rahma, E. H., \& Narasinga Rao, M. S. (2002). Effect of debittering treatment on the composition and protein components of lupin seed (Lupinus termis) flour. Journal of Agricultural and Food Chemistry, 32(5), 1026-1030. http://dx.doi.org/10.1021/jf00125a020

Rosell, C. M., Rojas, J. A., \& Benedito de Barber, C. (2001). Influence of hydrocolloids on dough rheology and bread quality. Food Hydrocolloids, 15(1), 75-81. http://dx.doi.org/10.1016/S0268005X(00)00054-0

Ruiz Junior, L. P., \& Hove, E. L. (1976). Conditions affecting production of protein isolate from lupin seed kernel. Journal of Science and Food Agriculture, 27, 667-674. http://dx.doi.org/10.1002/jsfa.2740270713

Sandhu, K. S., Singh, N., \& Malhi, N. S. (2007). Some properties of corn grains and their flours I: Physicochemical, functional and chapatimaking properties of flours. Food Chemistry, 101(3), 938-946. http:// dx.doi.org/10.1016/j.foodchem.2006.02.040

Sharadanant, R., \& Khan, K. (2003). Effect of hydrophilic gums on the quality of frozen dough: II. Bread characteristics. Cereal Chemistry, 80(6), 773-780. http://dx.doi.org/10.1094/CCHEM.2003.80.6.773

Sosulski, F. W., \& Youngs, C. G. (1979). Yield and functional properties of classified protein and starch fractions from eight flours. Journal of American Oil Chemists' Society, 56, 292-295. http://dx.doi. org/10.1007/BF02671477 
Sousa, I. M. N., Morgan, P. J., Mitchell, J. R., Harding, S. E., \& Hill, S. E. (1996). Hydrodynamic characterization of lupin proteins solubility, intrinsic viscosity and molar mass. Journal of Agricultural and Food Chemistry, 44(10), 3018-3021. http://dx.doi.org/10.1021/jf950516f

Von Müller, A. R., López, C. B., Eynard, A. R., \& Guzmán, C. A. (2009). Subchronic toxicological evaluation of brea gum (Parkinsonia praecox) as a food additive in BALB / c mice. Drug and Chemical Toxicology, 32(4), 307-311. PMid:19793021. http://dx.doi. org/10.1080/01480540902976903
Wang, J., Rosell, C. M., \& Benedito de Barber, C. (2002). Effect of the adittion of different fibres on wheat dough performance and bread quality. Food Chemistry, 79(2), 221-226. http://dx.doi.org/10.1016/ S0308-8146(02)00135-8

Zaidul, I. S. M., Hiroaki, Y., Sun-Ju, K., Naoto, H., \& Takahiro, N. (2006). RVA study of mixtures of wheat flour and potato starches with different phosphorus contents. Food Chemistry, 102, 1105-1111. http://dx.doi.org/10.1016/j.foodchem.2006.06.056 